\title{
Innovation of Rotary Furnace to Make Shell Charcoal into Briquette to Increase the Yield of Product
}

\author{
Erwana Dewi ${ }^{1, *}$ Zamheri Zamheri ${ }^{1}$ M.Yerizam ${ }^{1}$ Zulkifli Zulkifli ${ }^{1}$ \\ ${ }^{1}$ State Polytechnic of Sriwijaya \\ *Corresponding author.Email: erwanadewi@gmail.com
}

\begin{abstract}
The purpose of this study is to innovate the drum tools used in the manufacture of shell charcoal, the process takes 8 to 10 hours, and a lot of smoke that causes pollution, as well as charcoal results obtained only $40 \%$, so the purpose of this study is to increase charcoal results and accelerate combustion time and improve the quality of shell charcoal produced. The Rotary Furnace in this result has specifications: Stainless material and steel Drum Length $130 \mathrm{~cm}$, Diameter $50.0 \mathrm{~cm}$, maximum feed capacity $20 \mathrm{~kg}$, minimum $3 \mathrm{~kg}$ The shell has maximum temperature are $300 \mathrm{oC}$ The innovation of Rotary Furnace has the best operation condition process is at temperature $200 \mathrm{oC}$, the highest yield of $68 \%$ with the lowest $\%$ loss of $23.4 \%$, the number of fireballs is $20 \%$, and the operating time for making charcoal into briquette are 15-30 minutes.
\end{abstract}

Keywords: coconut shell, fire ball, Rotary Furnace, charcoal.

\section{INTRODUCTION}

Many people are interested on the business in the field of charcoal production from coconut shell. This is also because it is encouraged by the many requests for activated charcoal shell, but the technology to process activated charcoal from this shell does not yet exist, this is what triggers researchers to develop process technology with the design of tools that can work efficiently and without any pollution caused. Introduction.

Currently the demand for activated charcoal or activated carbon from shells is increasing sharply and the import market will buy activated charcoal products at a fairly high price as well. So many people are interested and take a business interest in the field of charcoal production from this coconut shell. This is also because it is encouraged by the many requests for activated shell charcoal, technology to process activated charcoal from this shell triggered researchers to develop process technology by designing tools that can work efficiently and without any pollution caused. Currently, the demand for charcoal from coconut shells continues to increase until it reaches 100 tons more per month, especially the demand from Middle Eastern countries.

\section{RESEARCH METHODOLOGY}

\subsection{Material and instruments}

Instruments : Tanki, Compressor, motor electrical 1/2 HP, binder, stack gas, holder, and matc.

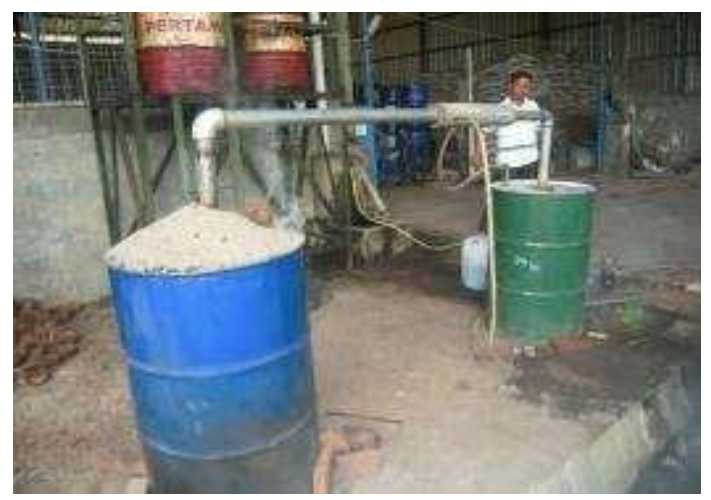

Figure 1 Old Technology are used for making carcoal in Small Industries 


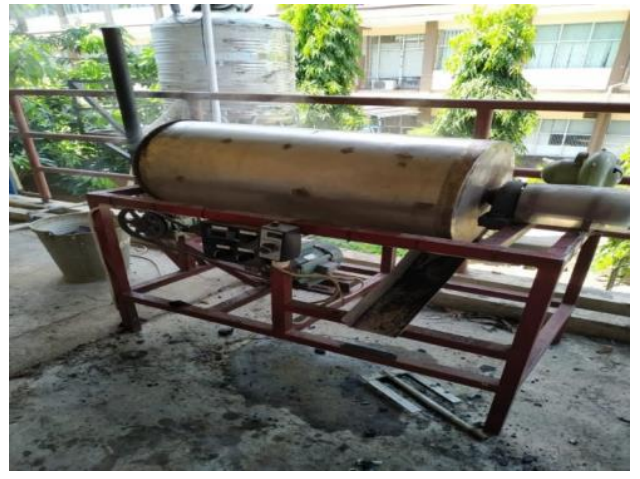

Figure 2 The Inovation Technology of Rotary Furnac for Making charcoal from coconut Shell was Studied

\section{RESULT AND DISCUSSION}

\section{Drum Performance spinning with a fireball}

In the first process starting from a charcoal fireball that has been lit outside the rotary drum dryer so that the process of authoring the coconut shell will begin the burning of the shell with the help of a fireball, this fireball can do the authoring of the shell with blow air from the compressor. The air from the compressor keeps the bait charcoal alive and can burn the shells around it. If the shell is done without using a fireball then the ignition process for combustion will take a long time because it waits until the shell fire is lit in the drum, and after the charcoal starts burning the drum is closed so that the shell does not burn out.

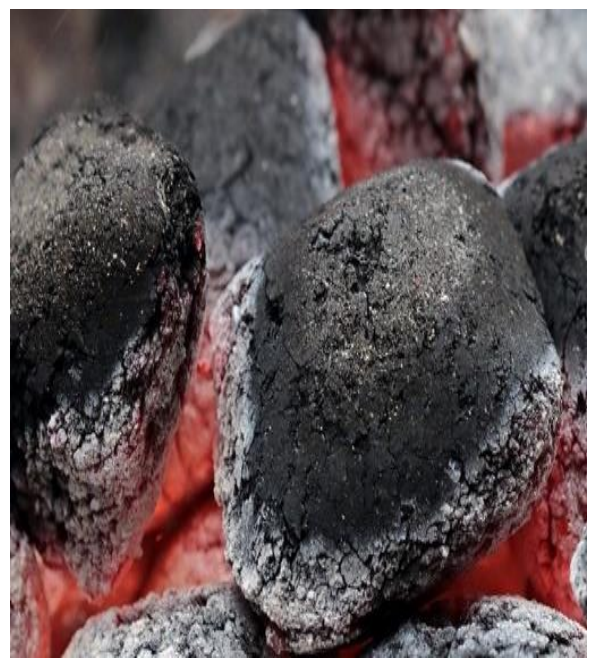

Figure 3. Fire ball.

The Inovation Technology were studied in these research Rotary drum for making charcoal from coconut shell.

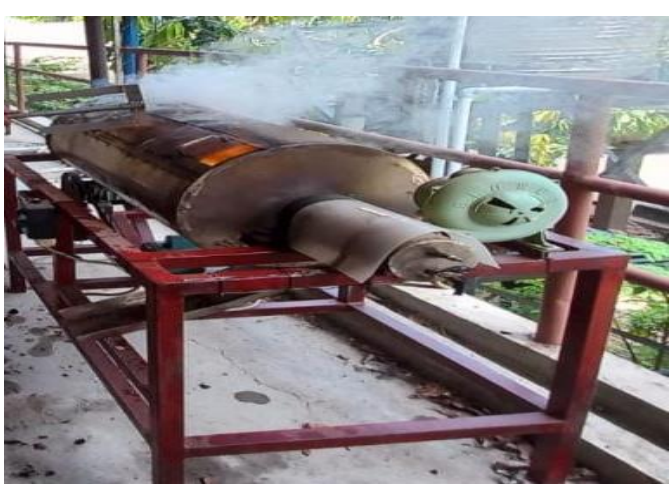

Figure 4. The Innovation Result of Rotary Furnace To Make Shell Charcoal Into Briquette

\subsection{Effect Of Temperature And Combustion Time On the \% Yield Of Products}

Temperature and time of authorship is a factor that is quite decisive in the process of making shell charcoal. The maximum temperature operating on a designed Rotary Dryer device can reach a maximum temperature of $300 \mathrm{oC}$. But in the experiment was not done because during the process of authoring with the addition of fireball have the maximum temperature reached was only $230 \mathrm{oC}$, so in this study the temperature of the tool was operated only up to $200 \mathrm{oC}$. The authoring processing time on the Tool is set from 130, 150, 180 and $200 \mathrm{oC}$.

But in the experiment was not done because during the process of authoring with the addition of a fireball the maximum temperature reached was only $230 \mathrm{oC}$, so in this study the temperature of the tool was operated only up to $200 \mathrm{oC}$. The time of processing time on the Tool is set from 130, 150, 180 and $200 \mathrm{oC}$. But in the experiment was not done because during the process of authoring with the addition of a fireball the maximum temperature reached was only $230 \mathrm{oC}$, so in this study the temperature of the tool was operated only up to $200 \mathrm{oC}$. The Time of processing on the Stirred Tank is set from 130, 150, 180 and $200 \mathrm{oC}$. The time of authorship is getting faster as the temperature increases. In the Graph it can be seen that the higher the temperature in the authoring process, the shorter the time needed and the \% yield also increases.

In the temperature Process at $200 \mathrm{oC}$ and the time used for 15 minutes get the highest $\%$ yield of $68 \%$, while the lowest $\%$ yield is $34 \%$ in operating conditions of $130 \mathrm{oC}$ for 60 minutes 


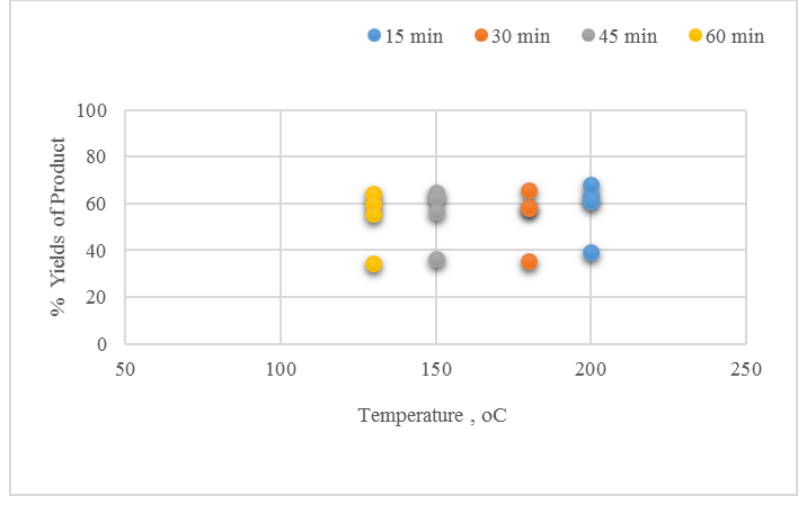

Figure 5. Effect of Temperature and Time of Operation on \% Yield of charcoal products

\subsection{The effect number of fireballs used on the $\%$ yield product and \% loss.}

The number of fireballs used as much as $10 \%$ to $30 \%$ of the weight of raw materials, in the use of $10 \%$ weight it turns out that the yield of the product obtained is very low even there is very little authoring. The use of large fireballs of $20 \%$ then the $\%$ yield obtained is also low because the \% loss and ash levels produced are quite high. In this study the best was on the number of fireballs by $20 \%$ with the highest $\%$ yield of $68 \%$ and $\%$ Loss also low $23.4 \%$ at the operating temperature of 200 oC within 15 minutes. . The effect of the amount of fireball weight on the temperature and time of combustion indicates that the higher the temperature, the fireball can make up the shell quickly and the time it takes to write it faster.

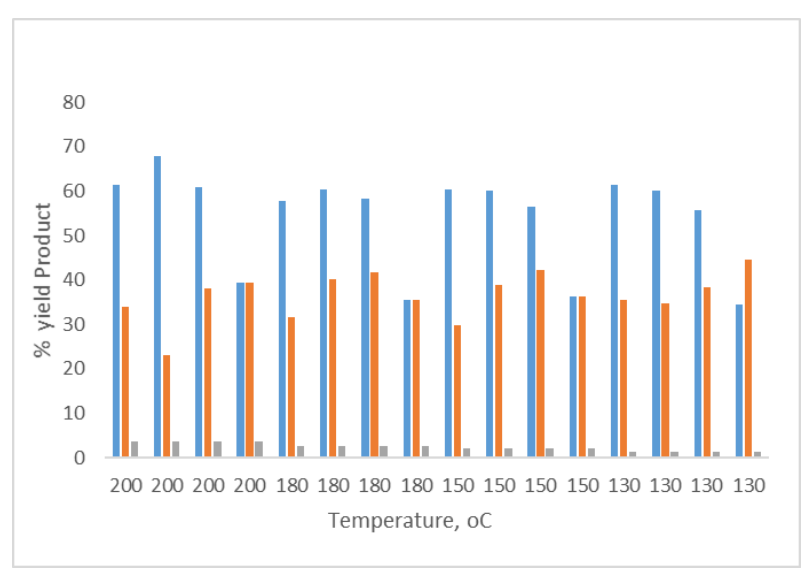

Figure 6 Effect of the number of fireballs are used on \% yield of Product

\subsection{Effect of temperature and the time process on \% loss}

Percent Shell loss is an unexpected result, because the more shells that do not become charcoal means the authoring process does not work, this will result in a low $\%$ yield.

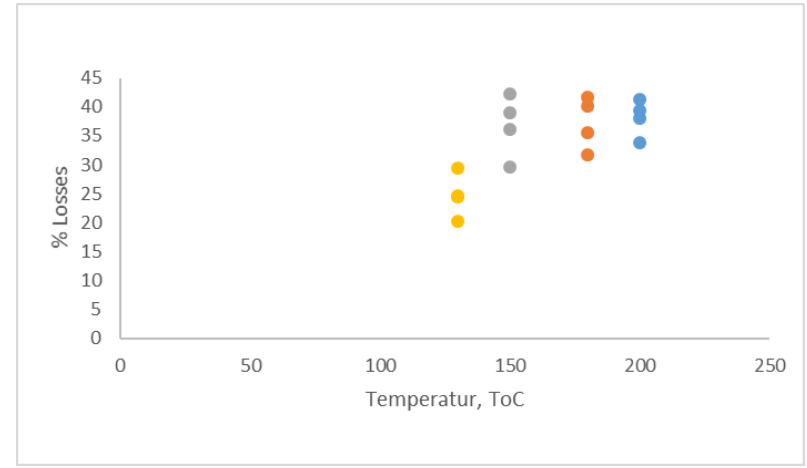

Figure 7 Effect of Temperature and time on the \% Loss

In the process of authoring the shell using a rotary dryer tool with a fireball also occurs Some shells that do not become charcoal, the results shown in graph 5 . is at a temperature of $150 \mathrm{oC}$ the largest amount of loss is $43 \%$ of the shell that does not burn, In this study, the influence of temperature and authorship time greatly affects the authorship process. If the time gets longer will also cause charcoal to ash, and high temperatures also affect the \% Yield, in this study the best temperature is $200 \mathrm{oC}$ where the highest yield percentage is $68 \%$ and 5 losses are lowest $23.4 \%$ with fireballs as much as $20 \%$, at 15 to 30 minutes

\section{CONCLUSION}

1. In these research on the Innovation of Rotary Furnace With Briquette for The Manufacture of Shell Charcoal, and using FireBall To Increase Percent Yield product.

2. The Operation Condition of Rotary Furnace are in Operating temperature $=200 \mathrm{oC}$, The highest yield is $68 \%$. the Lowest \% Loss 23.4 , by using $20 \%$ fireball, with Operating time 30 minutes.

3. The Innovation have been done, these research can be continued to the industry as a user and can be applied in the community.

\section{REFERENCES}

[1] Anonymous, 2006, 'Guidelines for Energy efficiency for Industry in Asia' www energyefficiencyasia.org.

[2] Bhattacharya S., C., 2001, A Study on improving Biomass Briquetting

[3] Hindarso, Herman, 2005. The process of converting biomass into bioarang as an alternative fuel Nicholas Tumbel, Ardi Kurniawan, December 2019, 'Coconut Shell Charcoal Processing using Modified Combustion Furnace', Journal of Industrial Technology Research, ISSN 2085-580x, vo.11 no.21 Kemenperin1. 2017. Active carbon exports 
[4]https://kemenperin.go.id/statistik/query_komoditi.ph p. Accessed September 2019.

[5] Robert H, Perry,1999. Perry's chemical Engineering Handbook, Mc-Graw Hill.Inc. Kemenperin1. 2017. Active carbon exports

[6]https://kemenperin.go.id/statistik/query_komoditi.ph p. Accessed September 2019.

[7] Robert H, Perry,1999. Perry's chemical Engineering Handbook, Mc-Graw Hill.Inc.
[8] Samsul, M.2004.'Effect of Addition of Coconut Shell Charcoal and Use of Adhesives on the properties of charcoal from wood powder'. Physicschemistry Briquette, Gajah Mada University.

[9] Tarwiyah, Kemal,2001, 'Appropriate Technology for Small Agroindustrials of West Sumatra, Hasbullah, Council of Sciences, Industrial Technology of West

Sumatra. 